\title{
ISOLATION OF COMPOUNDS ATTRACTIVE TO THE LEAF-CUTTING ANT Atta sexdens rubropilosa FOREL (HYMENOPTERA: FORMICIDAE) FROM Mabea fistulifera ELAIOSOME
}

\author{
Ethel Fernandes de O. Peternelli* \\ Departamento de Biologia Animal, Universidade Federal de Viçosa, 36571-000 Viçosa - MG, Brasil \\ Luiz C. A. Barbosa \\ Departamento de Química, Universidade Federal de Viçosa, 36571-000 Viçosa - MG, Brasil \\ Terezinha M. C. Della Lucia \\ Instituto de Biotecnologia Aplicada à Agropecuária, Universidade Federal de Viçosa, 36571-000 Viçosa - MG, Brasil
}

Recebido em 1/9/06; aceito em 6/9/07; publicado na web em 26/2/08

\begin{abstract}
Mabea fistulifera (Euphorbiaceae) is a pioneer plant species with seeds dispersed by the ant Atta sexdens rubropilosa. Since the ants are attracted to the seeds to use its elaiosome as a source of energy, we investigated its composition. The elaiosomes from 13,000 seeds were extracted with a methanol:chloroform mixture $(2: 1 \mathrm{v} / \mathrm{v})$ and yielded $22 \%$ of a residue. This residue was fractionated by column chromatography and its composition determined by infrared spectroscopy and chromatography/mass spectrometry (GC-MS). The elaiosome lipids are constituted mainly by free fatty acids, triacylglycerols and minor quantities of monoacylglycerols or diacylglycerols.
\end{abstract}

Keywords: elaiosome; fatty acids; Mabea fistulifera.

\section{INTRODUCTION}

The interaction between ants and myrmecochoric seeds is influenced by the characteristics of the diaspores such as size ${ }^{1}$, presence of the lipid containing appendage, the elaiosome ${ }^{2}$ and the ant size $^{3}$.

Chemical composition of the elaiosome and seeds, mainly the lipid content, also plays a fundamental role in this interaction ${ }^{4}$. The importance of the lipids, specially the fatty acids, as possible mediators of ant-seed interaction has been mentioned by several autors ${ }^{4-7}$. Seed elaiosome has been reported as the attractant to the ants in the mutualism between myrmecochoric plants and seed dispersing ants ${ }^{8}$. The elaiosome is a nutritious appendage bound to the seed and consists of modified cells, forming vacuoles where there is a rich mixture of fatty acids, lipids and proteins ${ }^{6,9}$. The elaiosome is variable in shape, size and color in each plant species where it occurs ${ }^{2,10}$.

The evolutionary origin of the elaiosome is not well known, but one of the hypotheses is that some plant species used to produce seeds that had an external seed coat for protection against predators. During plant evolution, this tissue went through chemical and structural modification and expanded to form the elaiosome. In addition to the protective function against predators, the elaiosome consequently became attractive to seed dispersing ants ${ }^{11}$.

The elaiosome is an additional food source to ants ${ }^{12}$ since these insects do not have certain routes of lipid biosynthesis. Ants also require a rich source of steroids in their diet ${ }^{9}$. In the chemical composition of the elaiosome there are many groups of lipids that stimulate ants to collect the seeds ${ }^{13}$. This attraction to leaf-cutting ants Atta sexdens rubropilosa was observed by Peternelli et al..$^{15}$ when ant workers transported the seeds of M. fistulifera to their nests, removed the elaiosome and subsequently discarded the seeds.

Leaf-cutting ants are important agriculture and forestry pests in South America and the main control method for them is the use

\footnotetext{
*e-mail: ethel@insecta.ufv.br
}

of attractive toxic baits. Therefore, it would be desirable to obtain more information on attractants to these pest insects and that could be used as baits for control measures.

The objective of this research was to determine the chemical composition of the elaiosome of the Euphorbiaceae Mabea fistulifera Mart., commonly known as "canudo-de-pito"14, a pioneer tree species ${ }^{16}$ in the region of Viçosa, Minas Gerais, Brazil..

\section{EXPERIMENTAL}

\section{Seed collection for extraction}

Seeds of $M$. fistulifera (Figure 1) are typically $1 \mathrm{~cm}$ in size and were hand collected in the field (Viçosa, Minas Gerais, Brazil; 20 $45^{\prime} \mathrm{S}$ e $42^{\circ} 55^{\prime} \mathrm{W}$ ) at the time of fruit maturation in September and October 2001 and in September 2002. Seed collections were divided in two forms. First, organza bags were placed around the seed bunches on the tree. These bags were monitored until fruit opening for seed collecting. This spontaneous fruit opening can be easily observed in sunny days ${ }^{15}$ by the sound produced by explosive fruit opening. In the second step, the seed bunches were cut from the trees and were taken to the laboratory where they were placed in trays, on a well ventilated room until fruit opening. The trays were covered with a screen during fruit drying to avoid seed loss. Collected seeds were divided in sub samples according to their collection date: Mf1 (Sep/ 2001), Mf2 (Oct/2001) and Mf3 (Sep/2002).

\section{Elaiosome components extraction and separation}

Elaiosomes of each seed were removed by hand using a scalp. They were weighed so that complete seed samples resulted in elaiosome samples only (Mf1, Mf2 and Mf3).

The three samples obtained, about $4 \mathrm{~g}$ of dry elaiosome for each one, were submitted to a continuous extraction with mixture of methanol and chloroform, $(2: 1 \mathrm{v} / \mathrm{v} ; 120 \mathrm{~mL}: 60 \mathrm{~mL})$ in a Soxhlet extractor for $48 \mathrm{~h}$. After extraction, the material was filtered and 


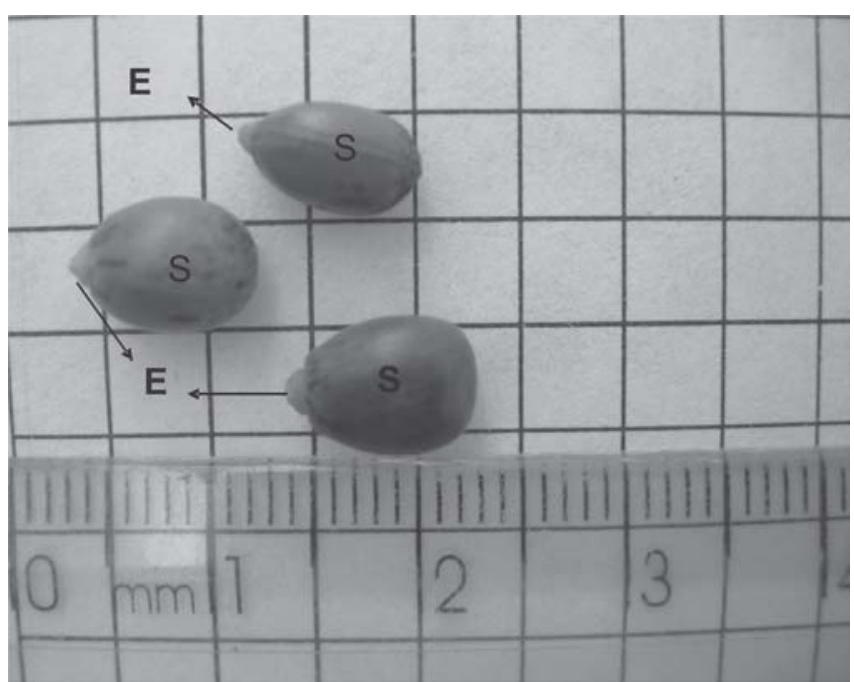

Figure 1. Seeds of Mabea fistulifera. (S) Seed body; (E) Elaiosome appendage. The square scale represents $1 \mathrm{~cm}^{2}$

the solvent removed under reduced pressure in a rotatory evaporator. The extracts Mf1E, Mf2E and Mf3E were weighed and stored at 4 ${ }^{\circ} \mathrm{C}$ until chromatographic analyzes were carried out ${ }^{13}$.

All fractions $(0.20 \mathrm{~g}$ each) were submitted to a silica gel (70$230 \mathrm{Mesh}$ ) column chromatography (35 $\mathrm{mm}$ i.d. and $25 \mathrm{~cm}$ in height), eluting with a mixture of hexane:diethyl ether $(3: 1 \mathrm{v} / \mathrm{v})$. The fractions obtained in each case, were monitored by silica gel TLC analysis with, using phosphomolybdic acid as a visualization reagent ${ }^{17}$. The fractions that were similar by TLC analysis were grouped, and the solvent evaporated under reduced pressure in a rotary evaporator.

\section{Gas chromatography and spectroscopic analyses}

The chromatography and spectroscopic analyses were carried out using a method described by Barbosa et al. ${ }^{21}$.

\section{Infrared analysis}

The infrared spectra of the extracts and their respective eluted fractions were obtained as a liquid film in $\mathrm{NaCl}$ cell using a Perkin Elmer FT-IR 1000 spectrophotometer.

\section{Transesterification of the triacylglycerol ${ }^{21}$}

A sample of triacylglycerols or monoacylglycerols or diacylglycerols $(20 \mathrm{mg})$ was dissolved in tetrahydrofuran $(0.5 \mathrm{~mL})$ in a test tube, and $0.5 \mathrm{M}$ sodium methoxyde in anhydrous methanol $(1 \mathrm{~mL})$ was added. The solution was maintained at $50{ }^{\circ} \mathrm{C} / 10 \mathrm{~min}$, before addition of glacial acetic acid $(50 \mu \mathrm{L})$, and water $(3 \mathrm{~mL})$. The methyl esters were extracted with hexane $(2 \times 5 \mathrm{~mL})$, and the organic phase was dried over $\mathrm{Na}_{2} \mathrm{SO}_{4}$, containing $10 \% \mathrm{NaHCO}_{3}$. After filtration, the solvent was removed under reduced pressure and the residue was dissolved in hexane $(0.5 \mathrm{~mL})$, prior to the $\mathrm{GC}$ and GC-MS analyses.

\section{Esterification of the fatty acids ${ }^{2}$}

A sample of the fatty acid mixture $(10 \mathrm{mg})$ was dissolved in boron trifluoride $\left(14 \% \mathrm{BF}_{3}\right.$ in methanol, $\left.0.5 \mathrm{~mL}\right)$. The solution was warmed at $60{ }^{\circ} \mathrm{C}$ for $10 \mathrm{~min}$, prior to the extraction with hexane (6 $\mathrm{mL})$. The organic phase was washed with brine $(2 \times 5 \mathrm{~mL})$, dried over $\mathrm{Na}_{2} \mathrm{SO}_{4}$, and concentrated under reduced pressure. The residue was dissolved in hexane $(0.5 \mathrm{~mL})$ and submitted to GC and GCMS analyses.
Gas chromatography and mass spectrometry

The samples were analyzed by both gas chromatography (Shimadzu GC-17A equipped with a flame ionization detector and by gas chromatography-mass spectrometry (GC-MS; Shimadzu GCMS-QP5050A apparatus). The GC-MS apparatus equipped with an ion trap detector, operating in electron impact mode at $(70 \mathrm{eV})$; scan speed 1000; scan interval 0.50 and fragments were scanned between 45 to $450 \mathrm{Da}$. Identical chromatographic conditions were used in both analyses: fused silica capillary SP2330 column model (30 $\mathrm{m}$ x 0.25 i.d. $\mathrm{mm} ; 0.25 \mathrm{~mm}$ film thickness); under the following conditions: carrier gas $\mathrm{N}_{2}$ (GC) or $\mathrm{He}$ (GC-MS), flow rate $1.33 \mathrm{~mL}$ $\mathrm{min}^{-1}$; injector temperature $220{ }^{\circ} \mathrm{C}$, detector temperature $250{ }^{\circ} \mathrm{C}$; column temperature was programmed to hold at $60{ }^{\circ} \mathrm{C}$ (isothermal for $10 \mathrm{~min}$ ), then ramped by $10{ }^{\circ} \mathrm{C} \mathrm{min}^{-1}$, to $220^{\circ} \mathrm{C}$, then isothermal at $220^{\circ} \mathrm{C}$ for $10 \mathrm{~min}$; injection volume was $1.0 \mu \mathrm{L}$ ( $1 \%$ solution in $\mathrm{CH}_{2} \mathrm{Cl}_{2}$ ), in split mode, with ratio of 1:10. Each component was identified by comparison of acquired mass spectrum with reference data from a commercially available database (Wiley 330.000) and comparison with standard samples. The chemical components amounts were calculated from the GC-17A peak area, and the results presented are the average of three replicate experiments.

The following standards were used: methyl miristate (C14:0); methyl palmitate (C16:0); methyl esterate (C18:0); methyl oleate (C18:1); methyl linolate (C18:2); methyl linolenate(C18:3) and methyl eicosanate (C20:0) in a $1000 \mathrm{ppm}$ solution $(1 \mathrm{mg} / \mathrm{mL})$. These standards were mixed by taking $100 \mu \mathrm{L}$ of each standard solution and diluted to obtain a final concentration of $142.8 \mathrm{ppm}$. The injected volume of either standards or samples was $1 \mu \mathrm{L}$.

\section{RESULTS AND DISCUSSION}

The masses of each extract obtained from the elaiosome extraction with a methanol: chloroform mixture and the masses of each fractions obtained by fractioning of each extract were illustrated on the Table 1.

Table 1. Mass ( $\mathrm{g}$ ) of each fraction obtained from the extracts Mf1, Mf2 and Mf3

\begin{tabular}{lcc}
\hline Extracts & Fractions & Mass $(\mathrm{g})$ \\
\hline Mf1 $(0.882 \mathrm{~g})$ & Mf1: 01-27 & 0.054 \\
& Mf1: 28-37 & 0.021 \\
Mf2 $(2.321 \mathrm{~g})$ & Mf1: 38-77 & 0.114 \\
& Mf2: 01-25 & 0.067 \\
Mf3 (1.078 g) & Mf2: 26-90 & 0.106 \\
& Mf3: 01-20 & 0.035 \\
& Mf3: 21-55 & 0.056 \\
\hline
\end{tabular}

The infrared spectra of the fractions Mf1:1-27, Mf2:1-25 and Mf3:1-20 (Figure 2A) were typical of fatty ester ${ }^{22}$, showing major absorptions at $3.007 \mathrm{~cm}^{-1}(\mathrm{v}=\mathrm{C}-\mathrm{H}), 2.955,2.923$ and $2.853 \mathrm{~cm}^{-1}(\mathrm{v}$ $\mathrm{C}-\mathrm{H}), 1.746$ ( $\vee \mathrm{C}=\mathrm{O}$ of ester), 1.463 and $1.377 \mathrm{~cm}^{-1}\left(\delta_{\mathrm{s}} \mathrm{C}-\mathrm{H}\right), 1.260$ $\mathrm{cm}^{-1}\left(v \mathrm{C}-\mathrm{O}\right.$ of ester) and $721 \mathrm{~cm}^{-1}\left[\delta_{\mathrm{s}}\left(\mathrm{CH}_{2}\right)_{\mathrm{n}} ; \mathrm{n}>4\right]$. These data indicated that the fractions listed above were constituted by triacylglycerols.

The infrared spectrum of fraction Mf1:28-37 (Figure 2B), presented characteristic absorptions of fatty ester at $1.740(\vee \mathrm{C}=\mathrm{O})$, $1102(v \mathrm{C}-\mathrm{O})$ and $719 \mathrm{~cm}^{-1}\left[\delta_{\mathrm{s}}\left(\mathrm{CH}_{2}\right)_{\mathrm{n}} ; \mathrm{n}>4\right]$, but showed also a strong band at $3.459 \mathrm{~cm}^{-1}$, characteristic of hydroxyl group ( $\left.\mathrm{VOH}\right)$. These dated suggested that this fraction if constituted by monoacylglycerols or diacylglycerols. These data are consistent with the literature ${ }^{13}$ that reported the presence of triacylglycerols 

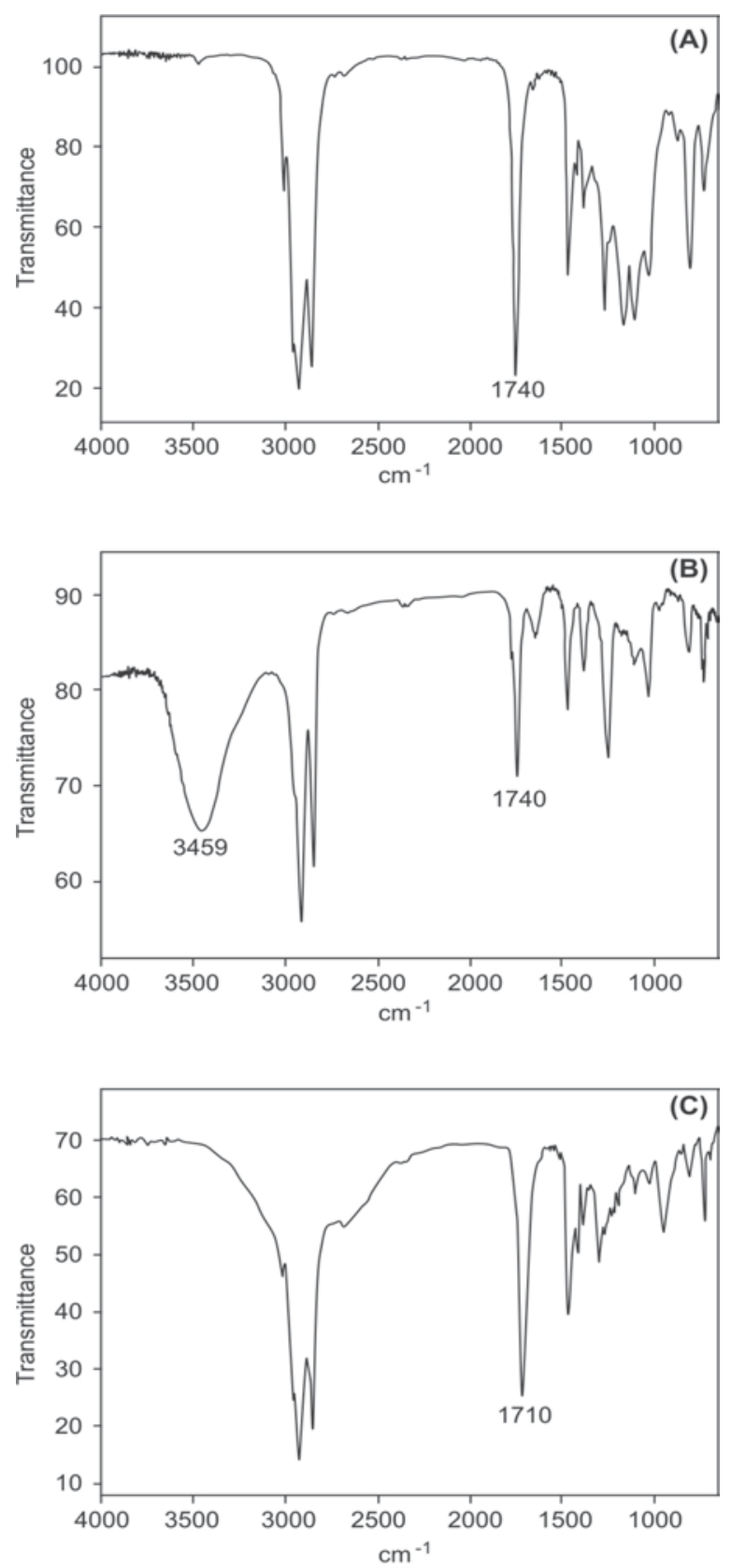

Figure 2. Infrared spectra of fraction, (A) - Mf1: 1-27, Mf2: 1-25 and Mf3: 120, typical of ester (triacylglycerols). (B) - Mf1: 28-37, typical of ester (monoacylglycerols or diacylglycerols). (C) - Infrared spectra of fraction Mf1: 26-90, typical of fatty acid

and diacylglycerols in the elaiosome of Jeffersonia diphylla, Sanguinaria canadensis, Trillum sessile and Dicentra cucullaria.

The infrared spectra of fractions Mf1:38-77, Mf2:26-90 and Mf3:21-55 (Figure 2C) showed absorptions typical of free fatty acids $^{22}$, with a large absorption band between 3.600 and $2.500 \mathrm{~cm}^{-1}$ $(\mathrm{V} \mathrm{OH})$ and absorptions at 2.953, 2.918 and $2.849 \mathrm{~cm}^{-1}(\mathrm{v} \mathrm{C}-\mathrm{H})$, $1.710(v \mathrm{C}=\mathrm{O}), 1.463\left(\mathrm{~cm}^{-1} \delta_{\mathrm{s}} \mathrm{C}-\mathrm{H}\right)$ and $720 \mathrm{~cm}^{-1}\left[\left(\delta_{\mathrm{s}}\left(\mathrm{CH}_{2}\right) \mathrm{n} ; \mathrm{n}>4\right]\right.$. In the literature ${ }^{18}$, the presence of fatty acid has also been reported in the lipophilic extract from the elaiosome of Pedicillate trillium species.

In general, the major components in the M. fistulifera elaiosome lipophilic extractives are free fatty acids, followed by triacylglycerols. The monoacylglycerols or diacylglycerols were present in only one fraction (Table 1,2). These results suggested that the lipid composition of the elaiosomes vary according to the time of seed production or with its maturation stage. Previous studies have demonstrated that the erucic acid content of seeds of Tropaeolum majus is dependent of the harvest period, raging from 33 to $64 \%{ }^{23}$. So, to better understand the influence of time or seed maturation and the chemical composition of the M. fistulifera elaiosomes, a more detailed investigation should be carried out.

Table 2. Fatty acid composition (\%) of free fatty acids, mono, di and triacylglycerols of the isolated fractions of Mabea fistulifera elaiosome

\begin{tabular}{lccccccc}
\hline $\begin{array}{l}\text { Fatty } \\
\text { Acids }\end{array}$ & \multicolumn{3}{c}{$\begin{array}{c}\text { Free Fatty } \\
\text { Acids }\end{array}$} & \multicolumn{3}{c}{ Monocylglycerols } & \multicolumn{3}{c}{ Triacylglycerols } \\
& or Diacylglycerols & & \\
& Mf1: & Mf2: & Mf3: & Mf1: & Mf1: & Mf2: & Mf3: \\
& $38-77$ & $26-90$ & $21-55$ & $28-37$ & $1-27$ & $1-25$ & $1-20$ \\
\hline C14:0 & 2.6 & 0.9 & 0.4 & 9.5 & 1.2 & 1.5 & 5.8 \\
C16:0 & 72.2 & 55.7 & 31.3 & 34.1 & 38.1 & 14.2 & 31.9 \\
C18:0 & 0.4 & 17.8 & 0.4 & 16.5 & 3.7 & 1.9 & 12.2 \\
C18:1 & 17.2 & 22.0 & 8.0 & 20.2 & 21.9 & 20.4 & 29.7 \\
C18:2 & 0.02 & 1.7 & 28.0 & 10.6 & 33.9 & 56.0 & 18.5 \\
C18:3 & 7.6 & 1.3 & 30.0 & 2.2 & 0.7 & 1.0 & 1.2 \\
C20:0 & - & 0.5 & 2.0 & 6.8 & 0.4 & 5.1 & 0.7 \\
\hline
\end{tabular}

In order to carry out a more detailed investigation of the composition of the fatty acids and fatty esters mixtures, they were converted into the corresponding methyl esters ${ }^{21}$. The characterization of the esters was carried out by CG and CG-MS analysis, and also by comparison with the chromatographic data of a mixture of the following standard methyl fatty esters: miristate (C14:0), palmitate (C16:0), stearate (C18:0), oleate (C18:1), linoleate (18:2), linolenate (C18:3) and icosanoate (C20:0).

The results of the analysis of the fatty acid composition of $M$. fistulifera elaiosomes are presente in Table 2. Palmitic acid (C16:0) was the most abundant fatty acid constituent in nearly all fractions, except for fraction Mf2:1-25, that was constituted mainly by linoleic acid (56.0\%). Linolenic (C18:3) and icosanoic acids (C20:0) were present in smaller concentration in all fractions (ranging from 0.4 to $6.8 \%$ ).

The large range of the fatty acid detected in the analysis of $M$. fistulifera elaiosome was similar to the results obtained by Soukup and Holman ${ }^{18}$ for the fatty acids of Pedicillate trillium (Trilliaceae). These authors indicated that the elaiosome has the function of providing the ant with an energetic food "bait" of easy access and did not have the attractiveness function. They suggested that ant attractiveness to the seeds occurs by an olfactory mechanism involving some volatile compounds secreted by the seed tissue or by the elaiosome itself.

An opposite view is provided by Marshall et al. ${ }^{19}$ and Kusmenoglu et $a l .{ }^{13}$, who believe the fatty acids composing the lipids are responsible for ant attraction and suggest that 1,2-diolein is the attractiveness component. Data obtained by Sheridan et al. ${ }^{20}$ also indicated that the ants do not find elaiosome containing seeds by means of olfaction but rather only after touching them with antennae.

Our results indicated that the elaiosome of $M$. fistulifera seeds is basically composed by lipids. Further investigation may elucidate if these lipids can be important as attractants or as an extra source of substrate for leaf-cutting ants and if they are used by these insects with different functions in their nutrition, physiology or behavior.

This is one of the pioneer investigations on the chemistry of elaiosomes of mirmecochoric plants and ant interaction in the Neotropical Region. Similar results can be verified in the literature for the temperate regions. Kusmenoglu et al. ${ }^{13}$ isolated lipids from 
the elaiosomes of four myrmecochores in deciduous forests of the USA; Soukup and Holman ${ }^{18}$ and Marshall et al. ${ }^{19}$ with North American seeds. Future studies using fractions and subfractions of the samples will be helpful in better understanding the real role these compounds play in the ant seed interaction.

\section{ACKNOWLEDGMENTS}

The authors are grateful to the Conselho Nacional de Desenvolvimento Científico e Tecnológico (CNPq) for financial support and fellowships (L. C. A. Barbosa and T. M. C. D. Lucia); to Fundação de Amparo à Pesquisa de Minas Gerais (FAPEMIG) for financial support; to Drs. P. Stansly and R. Muchovej, University of Florida, Southwest Florida Research and Education Center (USA), for valuable comments and revision of this manuscript. We also acknowledge Dr. C. G. S. Marinho (DBA-UFV) and anonymous referee for their helpful suggestions.

\section{REFERENCES}

1. Gorb, S. N.; Gorb, E. V.; Oikos 1995, 73, 367.

2. Mark, S.; Olesen, J. M.; Oecologia 1996, 107, 95.

3. Pizo, M. A.; Passos, L.; Oliveira, P. S. In Seed fate: Predation and secondary dispersal; Forget, P. M.; Lambert, J. E.; Hulme, P. E.; van der Wall, S. B., eds.; CABI Publishing: Oxfordshire, 2004

4. Pizo, M. A.; Oliveira, P. S.; Plant Ecol. 2001, 157, 37.

5. Bono, J. M.; Heithaus, E. R.; Insectes Soc. 2002, 49, 320.
6. Ciccarelli, D.; Andreucci, A. C.; Pagni, A. M.; Garbari, F.; Flora 2005 , 200, 326.

7. Fischer, R. C.; Ölzan, S. M.; Wanek, W.; Mayer, V.; Insectes Soc. 2005, $52,55$.

8. Beattie, A. J.; Culver, D. C.; Ecology 1981, 62, 107.

9. Hanzawa, F. M.; Beattie, A. J.; Culver, D. C.; Am. Nat. 1988, 131, 1.

10. Kaspari, M.; Oecologia 1996, 105, 397.

11. Handel, S. N.; Beattie, A.; J. Sci. Am. 1990, 263, 76.

12. Davidson, D. W.; Morton, S. R.; Oecologia 1981, 50, 357.

13. Kusmenoglu, S., Rockwood, L. L.; Gretz, M. R.; Phytochemistry 1989, 28, 2601.

14. Lorenzi, H.; Árvores brasileiras: manual de identificação e cultivo de plantas arbóreas nativas do Brasil, Ed. Plantarum: Nova Odessa, 2000, vol. $1,3^{\mathrm{a}}$ ed.

15. Peternelli, E. O.; Della Lucia, T. M. C.; Peternelli, L. A.; Martins, S. V.; Borges, E. E. L.; Sociobiology 2003, 42, 597.

16. Daud, R. D.; Feres, R. J. F.; Rev. Bras. de Zool. 2004, 21, 453.

17. Casey, M.; Leonard, J.; Lygo, B.; Procter, G.; Advanced practical organic chemistry, Chapman and Hall: New York, 1990.

18. Soukup, V. G.; Holman, R. T.; Phytochemistry 1987, 26, 1015.

19. Marshall, D. L.; Beattie, A. J.; Bollenbacher, W. E.; J. Chem. Ecol. 1979, 5,335 .

20. Sheridan, S. L.; Iversen, K. A.; Itagaki, H.; J. Insect Physiol. 1996, 42, 149.

21. Barbosa, L. C. A.; Barcelos, F. F.; Demuner, A. J.; Santos, M. A.; Nematropica 1999, 29, 81 .

22. Barbosa, L. C. A.; Espectroscopia no infravermelho na caracterização de compostos orgânicos, Editora UFV: Viçosa, 2007.

23. Castellani, D. C.; Dissertação de Mestrado, Universidade Federal de Viçosa, Brasil, 1997. 